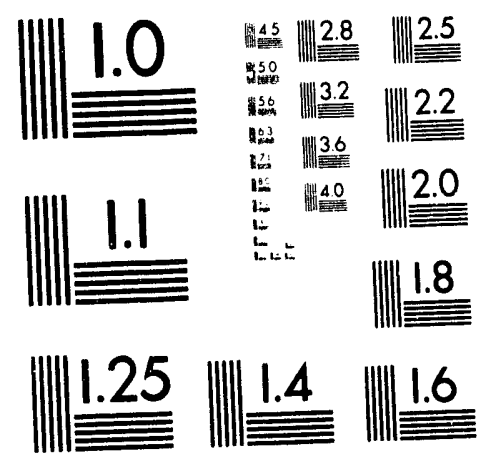



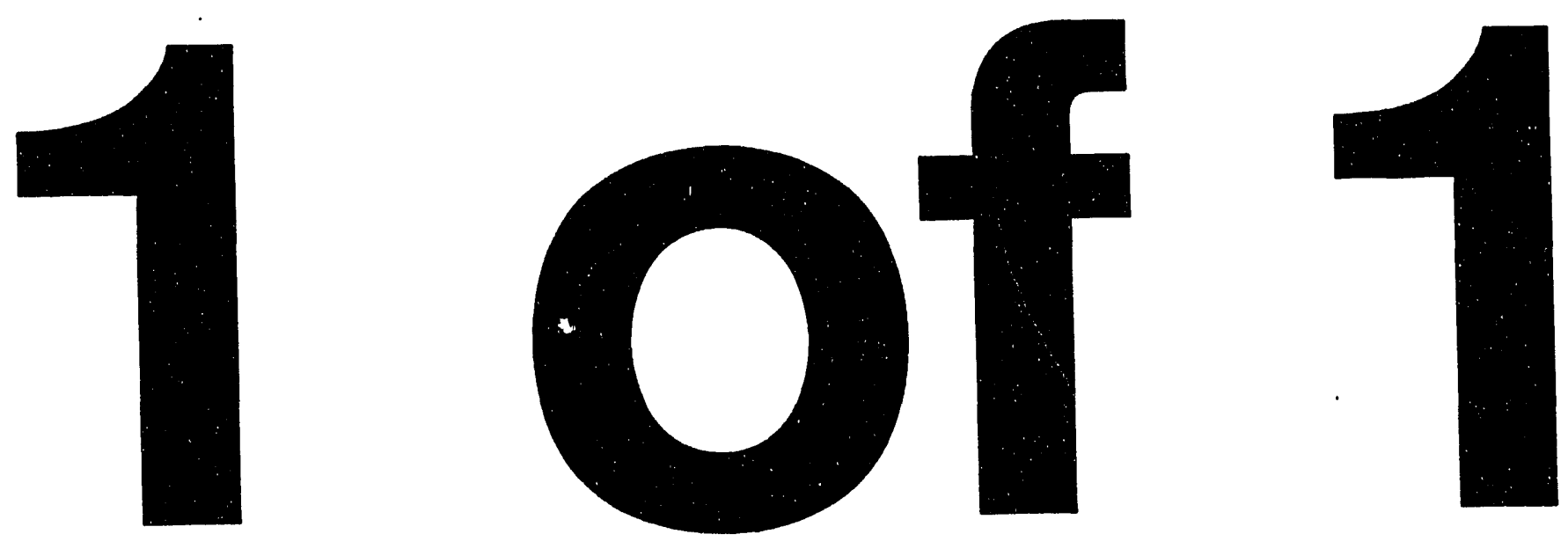
Invited Lectures (2) Paper

"Materials and Crystallographic Aspects of High $\mathbf{T}_{c}$ Superconductivity"

[NATO Advanced Study Institute] Erice, Sicily staky
May 17-29, 1993

May 17-29, 1993 .

\title{
STRUCTURE-PROPERTY RELATIONSHIPS IN RADICAL-CATION (ELECTRON-DONOR MOLECULE) AND ANION-BASED (INCLUDING FULLERIDES) ORGANIC SUPERCONDUCTORS AND THEIR USE IN THE DESIGN OF NEW MATERIALS
}

\author{
JACK M. WILLIAMS, K. DOUGLAS CARLSON, ARAVINDA M. KINI, \\ H. HAU WANG, URS GEISER, JOHN A. SCHLUETER and \\ ARTHUR J. SCHULTZ \\ Argonne National Laboratories \\ Chemistry and Materials Science Divisions \\ 9700 S. Cass Avenue \\ Argonne, IL 60439
}

JAMES E. SCHIRBER, EUGENE L. VENTURINI and

DONALD L. OVERMYER

Sandia Laboratories

Albuquerque, NM 87185

MYUNG-HWAN WHANGBO

Department of Chemistry

North Carolina State University

Raleigh, NC 27695

\begin{abstract}
The presently known structure-property relationships that have been developed for organic superconductors based on the ET molecule (b-phases and k-phases), and the C60-anion-based fullerides, and their use in the structural design of new superconducting materials are discussed.
\end{abstract}

\section{Introduction}

Whereas most organic substances are insulators, there is a class of conducting organic materials known as "synthetic metals" or "organic metals." Amongst the thousands of existing organic substances a very few, but steadily rising number, are superconducting at ambient pressure or under modest applied pressures. 1 The "molecular components" from which organic superconductors are derived are given in Figure 1, and a listing of these superconductors other than those derived from $\mathrm{C}_{60}$ is given in Table 1 .

\section{DISCLAIMER}

This report was prepared as an account of work sponsored by an agency of the United States Government. Neither the United States Government nor any agency thereof, nor any of their employees, makes any warranty, express or implied, or assumes any legal liability or responsibility for the accuracy, completeness, or usefulness of any information, apparatus, product, or process disclosed, or represents that its use would not infringe privately owned rights. Reference herein to any specific commercial product, process, or service by trade name, trademark, manufacturer, or otherwise does not necessarily constitute or imply its endorsement, recommendation, or favoring by the United States Government or any agency thereof. The views and opinions of authors expressed herein do not necessarily state or reflect those of the United States Government or any agency thereof.
The submifted manuscript has been athored by a contractor of the U. S. Goverment under controct No. W-31-109-ENG-38. Accordingly. the U. S Government retains a nonexclusive, roydty-free licence to publish or reproduce the published form of this contritution. $\alpha$ allow others to do so. for U.S. Goverment purposes.

\section{MASTER}


Fig.1. Molecular components of organic superconductors.

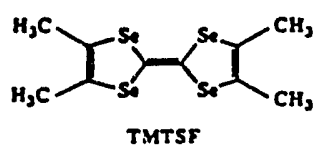<smiles>CCOCCSC1SC2SCCSC2S1</smiles>

DMET<smiles>C1CSC2SC(C3SC4SCSC4S3)SC2S1</smiles>

MET<smiles>C1CS[C@H]2SC([C@@H]3S[C@@H]4SCCS[C@@H]4S3)SC2S1</smiles><smiles>C1CSC(C2SC3SCC[SH]3S2)S1</smiles><smiles>C1CSC(C2SCCS2)C1</smiles>

TTF<smiles>C1COC2SC(C3SC4OCCOC4S3)SC2O1</smiles>

BEDO.TTY

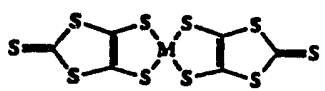
$\left(M\left(d m l()_{2}\right)^{3-}\right.$

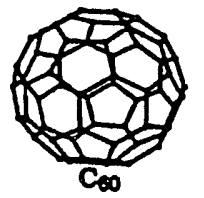

Table 1. Radical-cation based organic superconductors and their critical temperatures.

\begin{tabular}{|c|c|c|c|}
\hline Compound & $T_{c} \dagger(\mathrm{K})$ & Compound & $T_{c} \dagger(\mathrm{K})$ \\
\hline 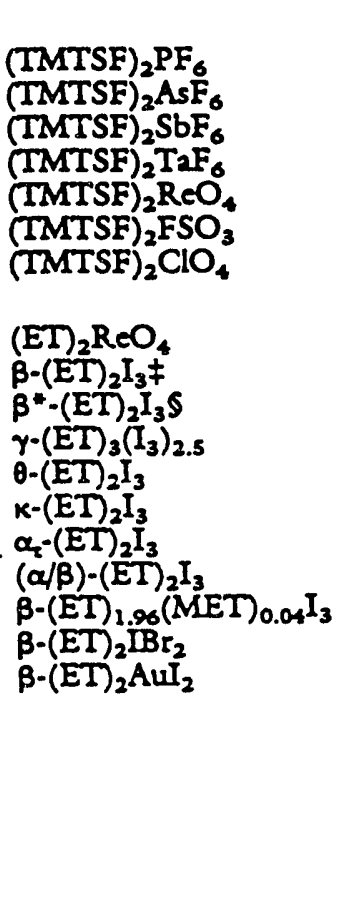 & $\begin{array}{c}\text { TMTSF compounds } \\
0.9 \text { (12 kbar) } \\
1.1(12 \mathrm{kbar}) \\
0.4(11 \mathrm{kbar}) \\
1.4(12 \mathrm{kbar}) \\
1.3(9.5 \mathrm{kbar}) \\
2.1(6.5 \mathrm{kbar}) \\
1.4 \\
\text { ET compounds } \\
2.0 \text { (4.5 kbar) } \\
1.4 \\
8.0(0.5 \mathrm{kbar}) \\
2.5 \\
3.6 \\
3.6 \\
7-8 \\
2.5-6.9 \\
4.6 \\
2.8 \\
4.98\end{array}$ & 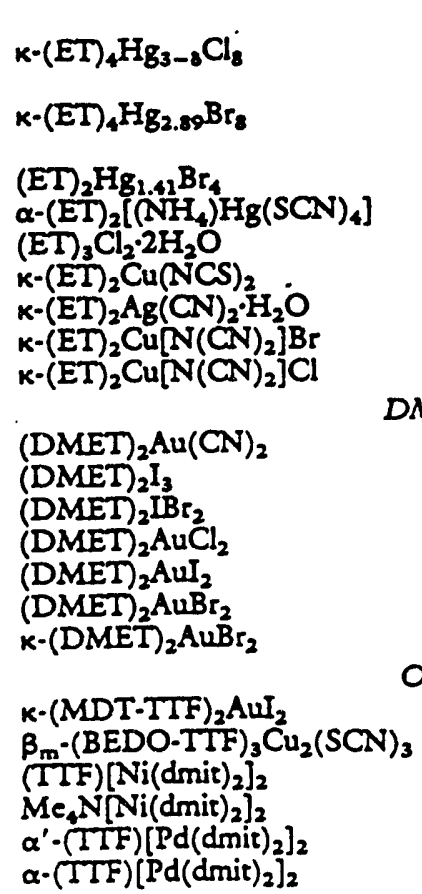 & $\begin{array}{l}1.8 \text { (12 kbar); } \\
5.3 \text { (29 kbar) } \\
4.3 ; \\
6.7(3.5 \mathrm{kbar}) \\
2.0 \\
1.15 \\
2.0 \text { (16 kbar) } \\
10.4 \\
5.0 \\
11.6 \\
12.8 \text { (0.3 kbar) } \\
\text { compounds } \\
0.8 \text { (5 kbar) } \\
0.47 \\
0.59 \\
0.83 \\
0.55(5 \mathrm{kbar}) \\
1.0 \text { (1.5 kbar) } \\
1.9 \\
: 0 \text { mpounds } \\
4.5 \\
1.06 \\
1.6(7 \mathrm{kbar}) \\
5.0(7 \mathrm{kbar}) \\
6.42(20.7 \mathrm{kbar}) \\
1.7(21.75 \mathrm{kbar})\end{array}$ \\
\hline
\end{tabular}

†At ambient pressure in those entries where no pressure is indicted in parentheses.

$\ddagger$ Also referred to as $\beta_{\mathrm{L}}-(\mathrm{ET})_{2} \mathrm{I}_{3} \quad$ \&Also referred to as $\beta_{\mathrm{H}}-(\mathrm{ET})_{2} \mathrm{I}_{3}$. 
The first organic superconductor, quasi-1D (TMTST) ${ }_{2} \mathrm{PF}_{6}\left(\mathrm{~T}_{\mathrm{c}}=0.9 \mathrm{~K}\right)$ required considerable pressure ( $p=9 \mathrm{kbar}$ ) to suppress a metal-insulator antiferromagnetic ordering iransition (spin density wave, SDW) that occurred at $\sim 16 \mathrm{~K} .^{2}$ Competition between magnetic (SDW) and superconducting ground states are often observed in organic superconductors and SDW driven transitions occur when the on-site electron-electron Coulomb repulsion exceeds the stabilization gained from delocalization. In such cases electrons are localized to reduce the Cculomb repulsion and the ground state is that of an antiferromagnetically-coupled insulator (Mott-Hubbard insulator). ${ }^{3}$ The original discovery of organic superconductors ${ }^{2}$ based on TMTSF (Bechgaard salts) resulted in rapid developments in the field and, to date, organic superconductors have been derived from electron-donor molecule (non-C 60 based) and anion-based $\left[\mathrm{M}(\mathrm{dmit})^{\mathrm{n}-}\right.$ and $\left.\mathrm{C}_{60}{ }^{3}\right]$ species (Fig. 1). Only the ET and $\mathrm{C}_{60}$-based systems have yielded a sufficiently large number of superconductors to allow the development of useful structure-property correlations (vide infra). The structures of these materials and these correlations, where they exist, will be the focus of this paper in so much that they can provide predictive power in the design of new superconducting organic systems.

\section{$\beta$ - and K-phase ET-based Organic Superconductors}

\section{$\beta$-PHASE SYSTEMS}

The $\beta$-(ET) $2 X$ materials, $X=$ triatomic and monovalent anion, are ambient-pressure superconductors with $\mathrm{T}_{\mathrm{c}}$ 's as follows, viz., $2.8 \mathrm{~K}\left(\mathrm{X}=\mathrm{IBr}_{2}{ }^{-}\right), 4.9 \mathrm{~K}\left(\mathrm{X}=\mathrm{AuI}_{2}\right)$ and $1.5 \mathrm{~K}$ (and $8 \mathrm{~K}$ at $\mathrm{p}>0.5 \mathrm{kbar}$ ) for $\mathrm{X}=\mathrm{I}_{3}^{-}$. An important feature of these systems is that they are isostructural, with the linear-triatomic anions occupying a cavity created by the ET-molecule ethylene-group hydrogen atoms formed from the "corrugated-sheet" layer-like packing of the electron-donor molecules, as shown in the stereodiagram in Fig. 2 . The $\beta$-phase salts are actually layered superconductors, with the repeat unit being one layer of the conducting electron-donor molecules (in a general crystallographic position in the triclinic space group $P \overline{1}$, see Fig. 3 ) and one layer formed by the anions (located on inversion symmetry centers). In these systems the organic molecules are oriented parallel to each other and the molecular stacking axis occurs along the unit cell diagonal direction. The short S...S intermolecular contacts less than $3.6 \AA$, the van der Waals S...S radius sum (see Fig. 3), are formed between nolecules on neighboring stacks and the resulting honeycomb retwork they create in $\beta$-(ET) 2 X systems is the electron conduction pathway in the donor-molecule layers (the anions are insulators). The effect of varying the linear-anion length is to change the unit cell volume in the same fashion, while also altering the network system of intra-and intermolecular S...S contacts. A representative set of linear anions that yield $\beta$ or $\beta$-like structures is given in Table 2 , in which anion length, unit cell volume, and $T_{\mathcal{C}}$ (if appropriate) are presented. 

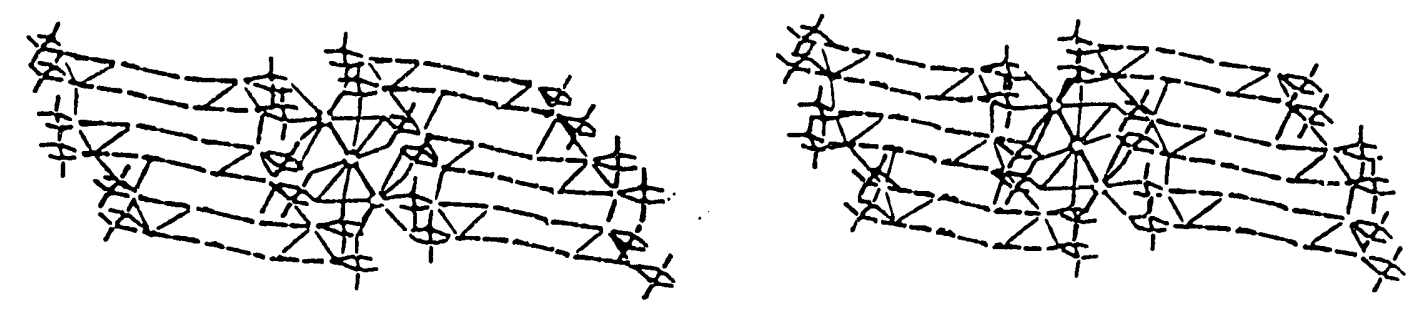

Fig. 2. Persepective view of a single $(\mathrm{X}-\mathrm{X}-\mathrm{X})^{-}$anion surrounded by ET molecule $-\mathrm{CH}_{2}$ groups, in the H-pocket made up of $12 \mathrm{ET}$ molecules in the $\beta$-(ET) $2 X$ structure.
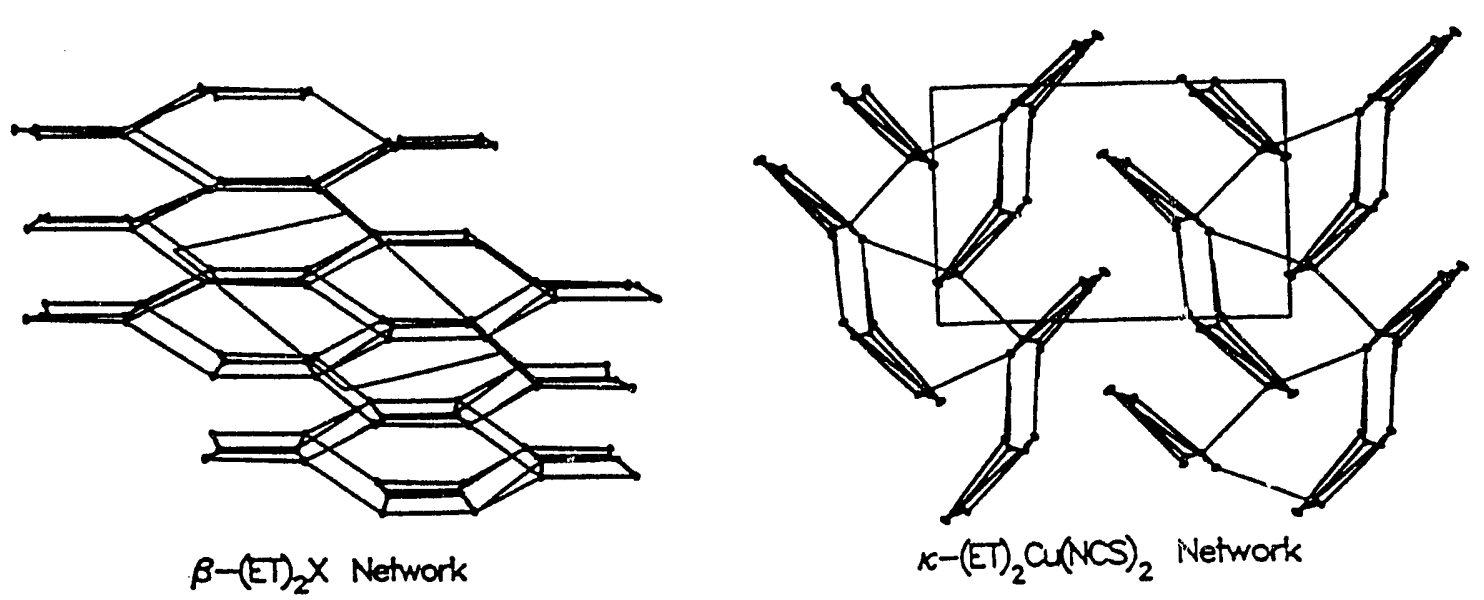

Fig. 3. ET molecule networks in $\beta$ - and $\kappa$-type organic superconductors. Thin lines indicate short intermolecular S...S contacts, and the unit cell boundaries are also indicated by faint lines. 
Table 2. $\beta$-(ET) $2 X$ Salts (Anions and Properties)

\begin{tabular}{|c|c|c|c|}
\hline$x$ & Anlon Length (A) & $V_{0}\left(\dot{A}^{3}\right.$ at $\left.298 K\right)$ & $\tau_{0}(K)$ \\
\hline I; & 10.1 & 855.9 & 1.5 \\
\hline AuI $_{2}$ & 8.4 & 845.2 & 5 \\
\hline $\mathrm{I}_{2} \mathrm{Br}^{-}$ & 9.7 & 842.3 & none \\
\hline $\mathrm{IBr}_{2}^{-}$ & 9.4 & 828.7 & 2.80 \\
\hline CilBr ${ }^{-}$ & 9.0 & 821.3 & $?$ \\
\hline $\mathrm{CCl}_{2}$ & 6.7 & 814.3 & $T_{M I}=22.1$ \\
\hline $\mathrm{AuCl}_{2}$ & 8.1 & 800.7 & $T_{M I} \approx 32$ \\
\hline
\end{tabular}

It is noteworthy that for the shortest anions, i.e., $\mathrm{ICl}_{2}^{-}$and $\mathrm{AuCl}_{2}^{-}$the salts undergo metal-insulator transitions below $40 \mathrm{~K}$ and the structures are only $\beta$-like due to the distortions of the regular $\beta$-lattice arising from $\mathrm{Cl} \cdots \mathrm{H}$ and anion-ET molecule interactions. It is important to further point out that anion-donor molecule contacts in the ET-anion systems are through weak $-\mathrm{CH}_{2} \cdots \mathrm{X}$ $\left(\mathrm{X}=\right.$ halide) hydrogen bonding interactions, and it is known the $\mathrm{T}_{\mathrm{c}}$ 's of the superconducting $\beta$-salts increase as these interactions increase in "softness" 1 of these contacts as longer anions are used due to an increase in electron-phonon coupling constants $(\lambda)$ in agreement with BCS theory. Softness increases as the length of the anion is increased due to a weakening of hydrogen bonding $-\mathrm{CH}_{2} \ldots \mathrm{X}$ interactions as the atomic number and electronegativity of the halogen $(\mathrm{X})$ increases, and also from a similar lengthening of the $S$...S contacts between ET molecules that parallels the increase in anion length. While the centrosymmetric anions $\left(\mathrm{I}_{3}^{-}, \mathrm{AuI}_{2}^{-}\right.$, and $\left.\mathrm{IBr}_{2}\right)$ provide ambient pressure superconductors, the unsymmetric $\mathrm{I}_{2} \mathrm{Br}^{-}$and $\mathrm{ClIBr}^{-}$anions produce nonsuperconducting products due to the disorder they induce in the lattice by random occupation of the crystallographic center of symmetry, which increases electron scattering and inhibits Cooper pair formation. Again, $\beta$-(ET) $2 \mathrm{I}_{3}$ is novel because a slight pressure of only $0.5 \mathrm{kbar}^{4}$ is sufficient to convert it from a modulated structure (below $\sim 175 \mathrm{~K}, \mathrm{~T}_{\mathrm{c}}=1.5 \mathrm{~K}$ ) to a fully ordered structure $\left[\beta^{*} \text {-(ET) }{ }_{2} I_{3}, T_{c}=8 \mathrm{~K}\right]^{5}$ which has the highest $T_{c}$ found in the $\beta$-phase organic superconductors. The three isostructural and centrosymmetric linear-anion salts $\left(\mathrm{I}_{3}^{-}, \mathrm{AuI}_{2}^{-}\right.$and $\mathrm{IBr}_{2} \rightarrow$ form the basis of a structure-property correlation that suggests $T_{c}$ 's as high as $40 \mathrm{~K}$ might result from the use of complex anions such as (NCS-M-SCN) ${ }^{-}$, (NCSe-M-SeCN) ${ }^{-}, \mathrm{M}=$ metal, etc., if they could be synthesized, were linear and could be incorporated into the $\beta$-(ET) $2 X$ structure (see Fig. 4). 


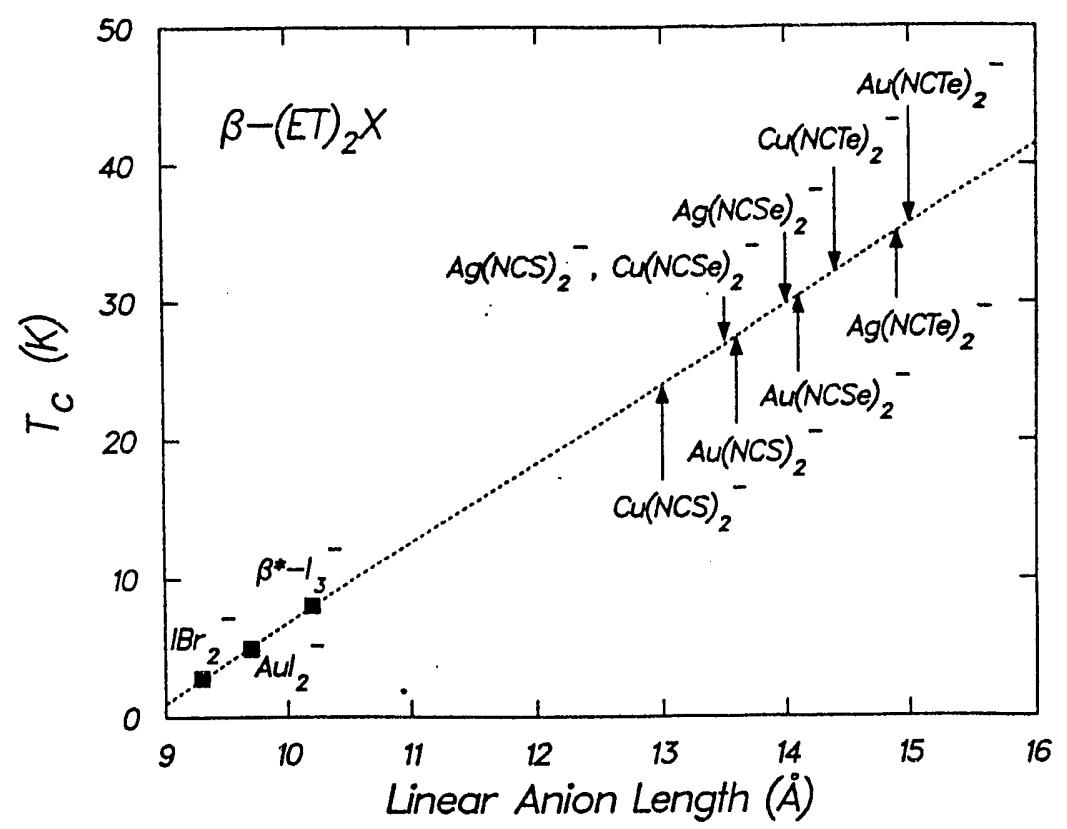

Fig. 4. Correlation of linear anion length in $\beta$-(ET) $2 X$ salts with superconducting critical temperature $T_{c}$ and possible new anionic derivatives with higher $\mathrm{T}_{\mathbf{c}}$ 's.

Finally, in the $\beta$-phase superconductors, the dependence of $T_{c}$ on $X^{-}$and pressure ${ }^{6}(p)$ is also related to changes in the lattice softness ${ }^{1}$ as a function of $X^{-}$and $p$, and a plot of $T_{c} v s$. $p$ is given in Figure 5.

Fig. 5. Pressure dependence of the $T_{c}$ of $\beta-(\mathrm{ET})_{2} \mathrm{X}\left(\mathrm{X}^{-}=\mathrm{I}_{3}^{-}, \mathrm{AuI}_{2}^{-}, \mathrm{IBr}_{2}^{-}\right)$.

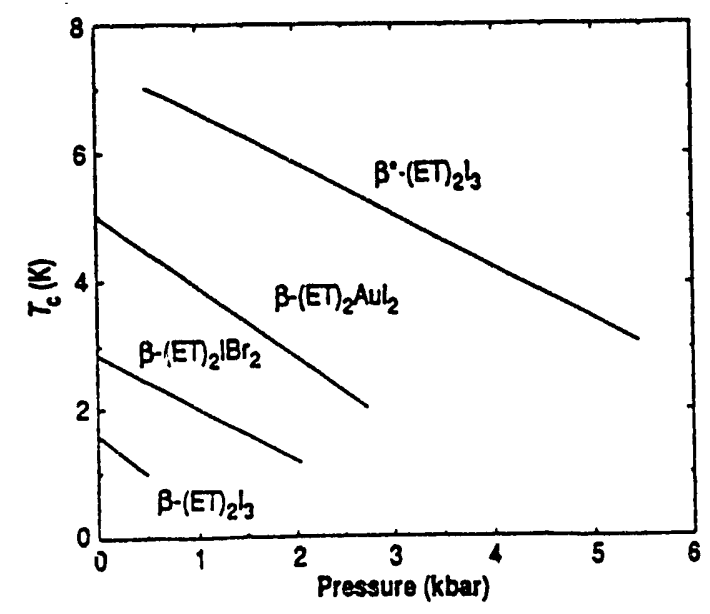

\section{K-PHASE SYSTEMS}

Another important type of molecular packing motif occurs in the " $K$-phase" ET-based materials, which contain orthogonally oriented ET-molecule dimers (see Fig. 3) and form layered superconductors possessing alternating layers of radical-cations and anions (the anions may be polymeric, see Fig. 6). 
Fig. 6. Layered structure of $x$-phase organic superconductors.

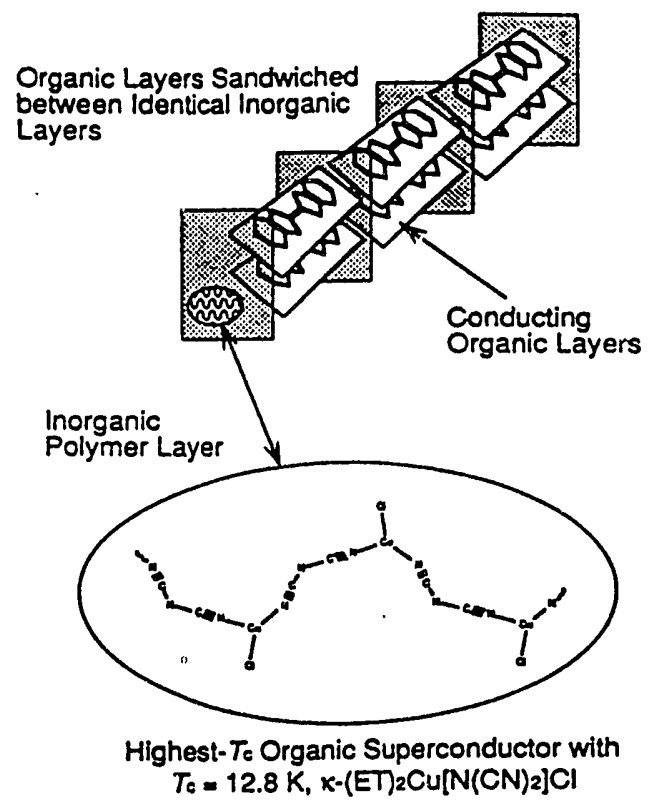

The resulting superconductors have $\mathrm{T}_{\mathrm{c}}$ 's as high as $12.8 \mathrm{~K}$ (the maximum presently observed for radical-cation systems). Attempts to prepare $\beta$-phase salts with the $\mathrm{X}=$ " $\mathrm{Cu}(\mathrm{NCS}){ }_{2}$ " (see Fig. 4) anion led to the first superconducting ET salt with a $T_{c}>10 \mathrm{~K}$, but with a $K$-phase, rather than $\beta$-packing motif. Furthermore, the " $\mathrm{Cu}(\mathrm{SCN})_{2}$ " anion is not linear, but is trigonal and polymeric. ${ }^{7}$ In fact, the highest $\mathrm{T}_{\mathrm{c}}$ 's observed in the ET-based superconductors are found in $K$-phase systems containing "self-assembling" polymeric anions derived from complexes of $\mathrm{Cu}^{+}$ (vide infra).

The $\kappa$-(ET) $2 \mathrm{Cu}(\mathrm{NCS})_{2}$ salt was unusual due to the presence of a polymeric anion derived from a trigonally coordinated $\mathrm{Cu}^{+}$ion. While attempting to prepare substituted salts of $\mathrm{Cu}^{+}$and the dicynamide $\left[\mathrm{N}(\mathrm{CN})_{2}\right]$ anion in place of $(\mathrm{SCN})^{-}$, three novel $\mathrm{x}$-phase derivatives, again containing polymeric anions (see Fig. 7), 8,9 were discovered, viz., $\mathrm{k}-(\mathrm{ET})_{2} \mathrm{Cu}\left[\mathrm{N}(\mathrm{CN})_{2}\right] \mathrm{X}, \mathrm{X}=\mathrm{Cl}^{-}, \mathrm{Br}^{-}$ and $\mathrm{I}^{-}$. The $\mathrm{X}=\mathrm{Br}^{-}$and $\mathrm{Cl}^{-}$salts exhibit the highest $\mathrm{T}_{\mathrm{c}}$ 's discovered in radical-cation based organic superconductors ${ }^{1}$ whereas, surprisingly, the $\mathrm{I}^{-}$derivative is a semiconductor. More importantly, even although these salts are isostructural they differ considerably in their electrical properties, i.e., the $\mathrm{Br}$-salt ${ }^{8}$ is an ambient pressure superconductor with $\mathrm{T}_{\mathrm{c}}=11.6 \mathrm{~K}$, the Cl-salt ${ }^{9}$ becomes superconducting $\left(T_{c}=12.8 \mathrm{~K}\right.$, the highest $T_{c}$ found in any ET-based superconductor) under the smallest pressure $(0.3 \mathrm{kbar})$ required to suppress a SDW transition for any organic superconductor. Furthermore, magnetization measurements at ambient pressure of the $\mathrm{Cl}^{-}$salt reveal an antiferromagnetic transition near $45 \mathrm{~K}$ and, for the first time in this class of materials, a transition near $22 \mathrm{~K}$ to a state exhibiting weak ferromagnetic hysteresis effects. ${ }^{10}$ 


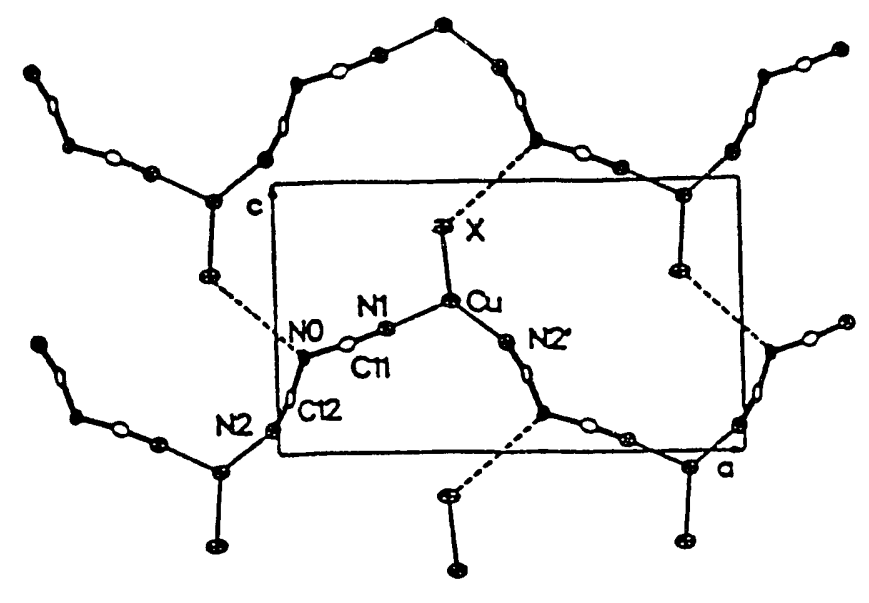

Fig. 7. $\mathrm{Cu}\left[\mathrm{N}(\mathrm{CN})_{2}\right] \mathrm{X}^{-}$anions $\mathrm{x}-(\mathrm{ET})_{2} \mathrm{Cu}\left[\mathrm{N}(\mathrm{CN})_{2}\right] \mathrm{X}, \mathrm{X}=\mathrm{Cl}^{-}, \mathrm{Br}^{-}, \mathrm{r}^{-}$

Calculations revealed that the band structures of the three $\mathrm{Cu}\left[\mathrm{N}(\mathrm{CN})_{2} \mathrm{X}^{-}\right.$salts are virtually the same and do not account for the differences in the observed electrical properties. ${ }^{1}$ The principal structural difference between the superconducting $\mathrm{Cu}\left[\mathrm{N}(\mathrm{CN})_{2}\right] \mathrm{X}, \mathrm{X}=\mathrm{Cl}^{-}, \mathrm{Br}^{-}$salts, and the semiconducting $\mathrm{X}=\mathrm{I}^{-}$derivative, is that whereas the former are crystallographically ordered at low temperatures, the $\mathrm{X}=\mathrm{I}^{-}$salt (which is not superconducting at $\mathrm{p}<5 \mathrm{kbar}$ ) is not due to the presence of ET-molecule $-\mathrm{CH}_{2}$-group disorder even at $16 \mathrm{~K} .^{1}$ An analysis based on the "lattice softness" concept, ${ }^{1}$ which arises from short intermolecular C-H $\cdots$ anion and C-H $\cdots H$ contacts in both the $\beta$ - and $K$-phase systems and it's relationship to $T_{c}$, has also been applied to the $\mathrm{Cu}\left[\mathrm{N}(\mathrm{CN})_{2}\right] \mathrm{X}, \mathrm{X}=\mathrm{Cl}^{-}, \mathrm{Br}^{-}, \mathrm{I}^{-}$salts with limited success. ${ }^{11}$ Finally, future anionic substitution reactions on trigonal $\mathrm{Cu}^{+}$ions may continue to provide new $\mathrm{K}$-phase derivatives with unusual electrical properties.

Attempts to develop structure-property relationships for the superconducting $K$-phase derivatives of ET have proven difficult, yet a first attempt at an empirical correlation is shown in Figure 8 by use of the data listed in Table 3. 


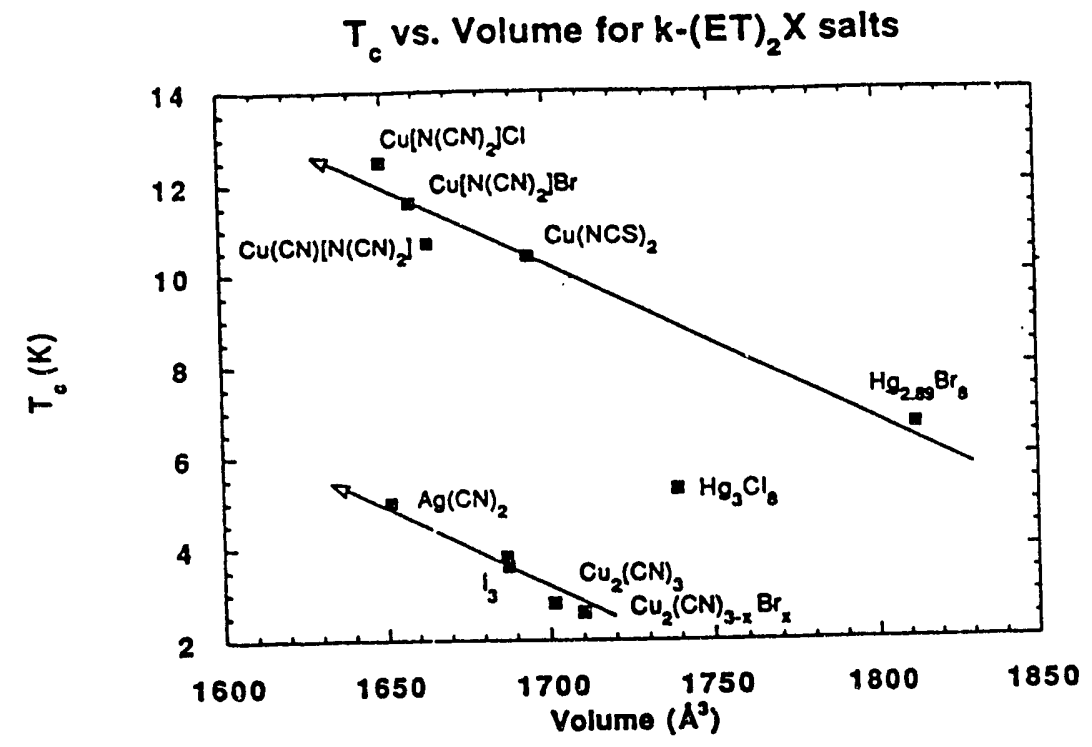

Fig 8. $T_{c}$ vs. $V_{c}$ for $K$-phase ET salts.

Table 3. The unit cell constants and $T_{c}$ 's for $K-(E T)_{2} X$ salts.

\begin{tabular}{|c|c|c|c|c|c|}
\hline Compound & $a(\mathcal{A})$ & $b(A)$ & $c(\AA)$ & $T_{c}(K)$ & Volume $\left(A^{3}\right)$ \\
\hline $\operatorname{CuN}(\mathrm{CN})_{2} \mathrm{I}^{*}$ & 12.960 & 8.680 & 30.340 & - & 1706.0 \\
\hline $\mathrm{Cu}(\mathrm{NCS})_{2}$ & 13.143 & 8.456 & 16.256 & 10.4 & 1694.8 \\
\hline $\mathrm{CuN}(\mathrm{CN})_{2} \mathrm{Br}^{\circ}$ & 12.942 & 8.539 & 30.016 & 11.6 & 1658.5 \\
\hline $\mathrm{CuN}(\mathrm{CN})_{2} \mathrm{Cl}$ & 12.977 & 8.480 & 29.979 & 12.5 & 1649.5 \\
\hline $\mathrm{Ag}(\mathrm{CN})_{2}\left(\mathrm{H}_{2} \mathrm{O}\right)$ & 12.593 & 8.642 & 16.080 & 5.00 & 1651.2 \\
\hline $\mathrm{I}_{3}$ & 12.832 & 8.466 & 16.387 & 3.60 & 1687.6 \\
\hline $\mathrm{H}_{83} \mathrm{Br}_{8}^{\circ}$ & 11.219 & 8.706 & 37.105 & 6.70 & 1812.0 \\
\hline $\mathrm{Hg}_{3} \mathrm{Cl}_{8}^{\circ}$ & 11.062 & 8.754 & 35.920 & 5.30 & 1739.0 \\
\hline $\mathrm{Cu}_{2}(\mathrm{CN})_{3}$ & 13.400 & 8.586 & 16.117 & 2.80 & 1701.2 \\
\hline $\mathrm{Cu}_{2}(\mathrm{CN})_{3-\mathrm{d}} \mathrm{Brd}$ & 13.400 & 8.590 & 16.250 & 2.60 & 1710.0 \\
\hline $\mathrm{Cu}\left[\mathrm{N}(\mathrm{CN})_{2}\right] \mathrm{CN}$ & 12.887 & 8.647 & 15.987 & 10.7 & 1664.0 \\
\hline $\mathrm{Cu}\left[\mathrm{N}(\mathrm{CN})_{2}\right] \mathrm{CN}$ & 13.324 & 8.543 & 16.093 & 3.80 & 1687.0 \\
\hline
\end{tabular}

The volume listed $=\frac{\text { anl voluman }}{2}$ becanse they contain double layer structures.

In the K-phases there appear to be separate correlations for different anion configurations based on either structurally 1-D anion (zig-zag) chains, such as found in $\mathrm{Cu}\left[\mathrm{N}(\mathrm{CN})_{2}\right] \mathrm{X}^{-}$salts (top line, Fig. 8), or structurally 2-D anion layers (2-D networks) in salts such as that observed in $K$-(ET) $2 I_{3}$ (bottom line, Fig. 8). However, in surprising contrast to the $\beta-(E T)_{2} X$ series, $T_{c}$ increases, rather than decreases, with decreasing unit cell volume. The basis of these empirical relationships is 
under intense study currently and a better understanding of their origin is required before rational design criteria can be developed for $K$-phase materials. Finally, based on years of experience gained by various investigators world-wide, the radical-cation (ET, etc.) superconductors are air-stable over long periods of time (years). However, they are brittle materials and not readily amenable to mechanical bending and forming.

\section{$\mathrm{C}_{60}$-based Organic Superconductors}

In distinct contrast to the nearly planar radical-cations derived from the ET molecule and similar electron-donor molecules given in Fig. 1, are the remarkable new superconductors derived from the essentially spherical and all carbon-containing electron-accepting buckminsterfullerene molecule, $\mathrm{C}_{60}$. Whereas the ET-based systems are usually $2 \mathrm{D}$ and of low symmetry (triclinic), the $\mathrm{M}_{3} \mathrm{C}_{60}$. $\mathbf{M}=$ alkali metal, organic superconductors are derived from the packing of spherical species $\mathbf{M}^{+}$ and $\mathrm{C}_{60}{ }^{3}$ ) to form cubic (isotropic) structures and, therefore are truly 3D conductors. In addition, the $T_{c}$ 's of the fullerides are substantially higher $\left(-33 \mathrm{~K}\right.$ in $\left.\mathrm{Rb}_{2} \mathrm{CsC}_{60}\right)$ than those presently known for the ET-based superconductors (present maximum $12.8 \mathrm{~K}$ ). Table 4 contains a list of relevant unit cell data and $\mathrm{T}_{\mathrm{c}}$ 's for the FCC (face centered cubic) alkali metal-based superconductors derived from $\mathrm{C}_{60}{ }^{3-}$. Based on existing data, it appears that no superconductors have been derived from purely $\mathrm{Li}$ or $\mathrm{Na}$ alone whereas pure and alloyed materials can be prepared by use of $\mathrm{K}, \mathrm{Rb}$ or $\mathrm{Cs}$.

Table 4. Unit cell and $\mathrm{T}_{\mathrm{c}}$ 's for FCC $\mathrm{M}_{\mathrm{x}} \mathrm{C}_{60}$ salts (from $\mathrm{D}$. W. Murphy, et al.). ${ }^{12}$

\begin{tabular}{|c|c|c|}
\hline & $\begin{array}{c}\text { Lattice } \\
\text { parameter(s) (A) }\end{array}$ & $\tau_{\mathrm{c}}(\mathrm{K})(\%) \dagger$ \\
\hline 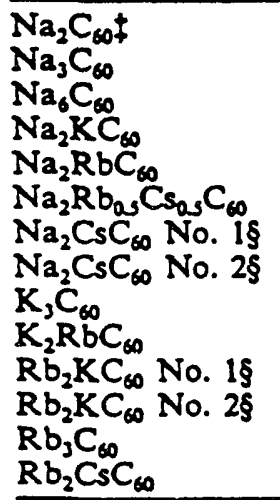 & $\begin{array}{l}14.189(1) \\
14.183(3) \\
14.380(8) \\
14.120(4) \\
14.091(6) \\
14.148(3) \\
14.132(2) \\
14.176(9) \\
14.253(3) \\
14.299(2) \\
14.336(1) \\
14.364(5) \\
14.436(2) \\
14.493(2)\end{array}$ & $\begin{array}{c}\bar{Z} \\
\bar{z} \\
8.0(3) \\
10.5(8) \\
14.0(9) \\
19.3(30) \\
21.8(32) \\
24.4(34) \\
26.4(32) \\
29.4(35) \\
31.3(48)\end{array}$ \\
\hline
\end{tabular}

The structures of the $\mathrm{M}_{3} \mathrm{C}_{60}$ salts are described as intercalation compounds of the FCC structure derived from $\mathrm{C}_{60}$ itself, or hypothetical BCC (body centered cubic) or BCT (body centered tetragonal) structures (vide infra). 12 For the FCC structures the octahedral and tetrahedral interstices are located on special positions in the space group with the octahedral site being larger than any alkali metal ion whereas the tetrahedral site most closely resembles $\mathrm{Na}^{+}$in size. The $\mathrm{C}_{60}$ structure and that of different $\mathrm{Mx}_{x}+\mathrm{C}_{60} \mathrm{n}^{\mathrm{n}}$ materials, including the $\mathrm{M}_{3} \mathrm{C}_{60}$ superconductors, are shown in Figure 9. 
a)

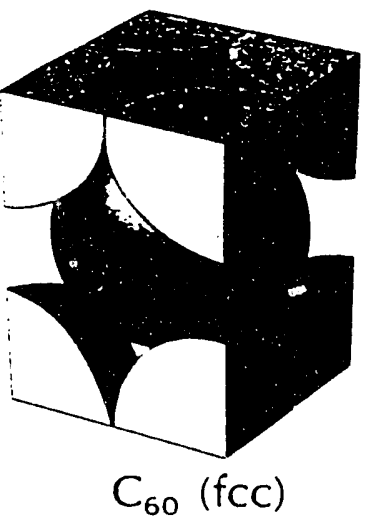

bct

d)

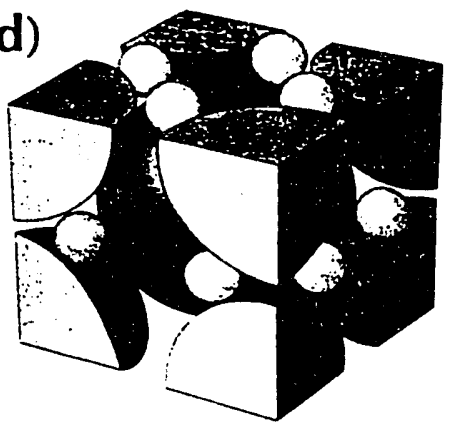

$\mathrm{A}_{4} \mathrm{C}_{60}$

bct b)

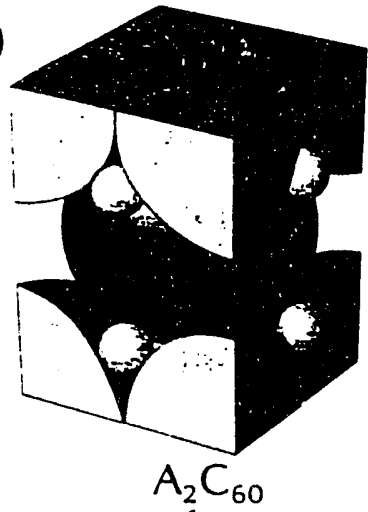

$\mathrm{fCC}$

e)

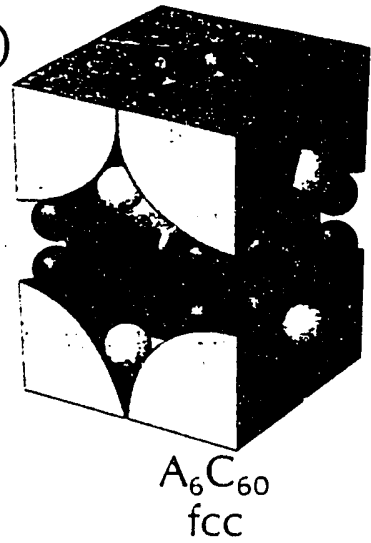

c)
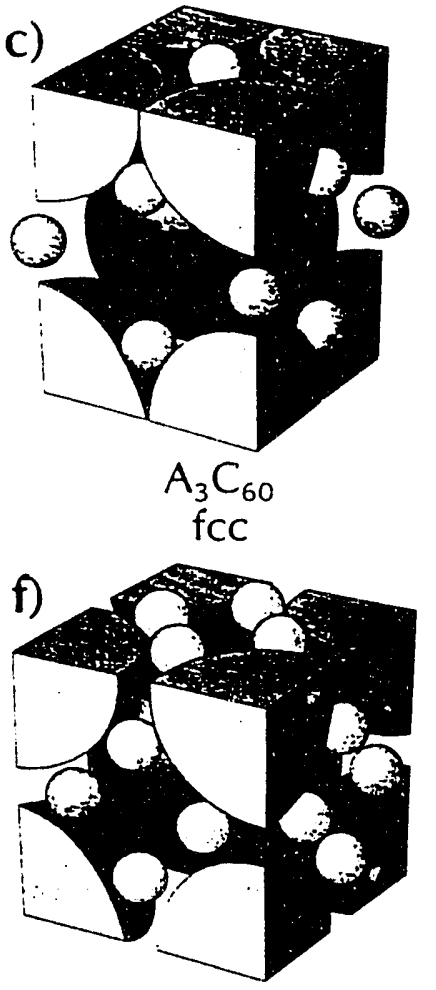

$\mathrm{A}_{6} \mathrm{C}_{60}$

bcc

Fig. 9. Schematic structures of $\mathrm{C}_{60}$ and $\mathrm{A}_{x} \mathrm{C}_{60}$ with $\mathrm{C}_{60}$ 's as large spheres and $A$ as the smaller spheres. (a) FCC $\mathrm{C}_{60}$ drawn in an equivalent BCT representation. (b) The structure of $\mathrm{Na}_{2} \mathrm{C}_{60}$ with $\mathrm{Na}$ ions in tetrahedral interstices. (c) $\mathrm{A}_{3} \mathrm{C}_{60}$ with $\mathrm{A}$ ions in both tetrahedral and octahedral interstices. (d) The $\mathrm{A}_{4} \mathrm{C}_{60}$ structure exhibited by $\mathrm{K}, \mathrm{Rb}$ and $\mathrm{Cs}$. (e) The FCC $\mathrm{A}_{6} \mathrm{C}_{60}$ structure $(\mathrm{A}=\mathrm{Na}, \mathrm{Ca})$ with the darker $\mathrm{Na}$ atom sites $50 \%$ occupied. (f) The $\mathrm{BCC} \mathrm{A}_{6} \mathrm{C}_{60}$ structure of $\mathrm{K}, \mathrm{Rb}$ and $\mathrm{Cs}$. (From D. W. Murphy, et al.). 12

From a detailed analysis of the salts of $\mathrm{C}_{60} \mathrm{n}^{\mathrm{n}}$, the structures they adopt agree with those one would predict on the basis of ion size $\left(\mathrm{M}^{+}\right.$and $\left.\mathrm{C}_{60}{ }^{\mathrm{n}}\right)$ and from electrostatic calculations. ${ }^{12}$ Since the $\mathrm{M}_{3} \mathrm{C}_{60}$ salts are isostructural, the $\mathrm{T}_{\mathrm{c}}$ 's scale with cation volume and unit cell size (see Fig. 10). 
Fig. 10. Superconducting $\mathrm{T}_{\mathrm{c}}$ 's plotted against calculated cation volume for $\mathrm{A}_{3} \mathrm{C}_{60}$ (from D. W. Murphy, et al.). 12

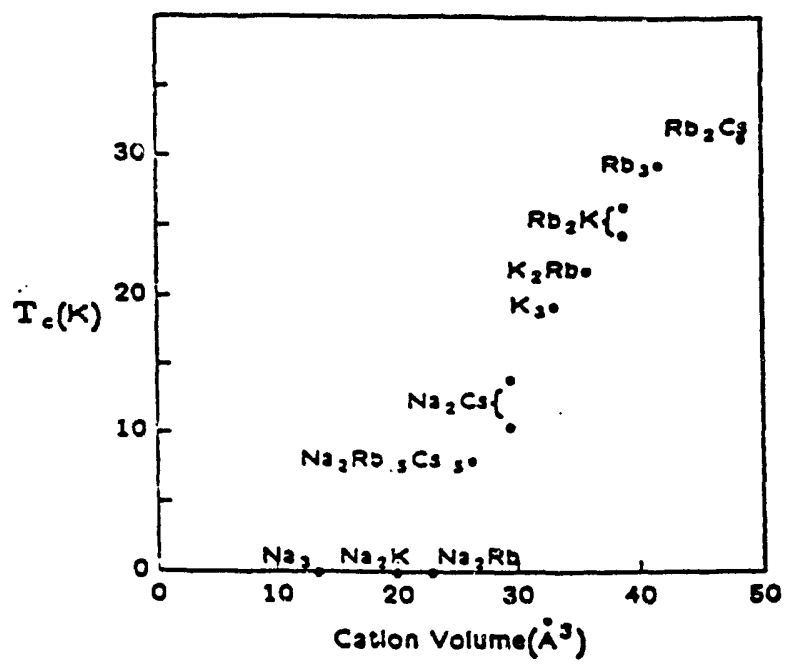

One of the surprising structural contrasts between the ET and $\mathrm{M}_{3} \mathrm{C}_{60}$ salts is that structural disorder in the former systems either reduces $T_{c}$ or destroys superconductivity altogether (e.g., $\left.\beta-(E T)_{2} I_{2} B r\right),{ }_{1}^{1}$ whereas the octahedral and tetrahedral sites of the alkali metal ions, and the $\mathrm{C}_{60} 0^{3-}$ spheres themselve, are highly disordered in the $\mathrm{M}_{3} \mathrm{C}_{60}$ superconductors. However, one structural feature common to both ET and $\mathrm{C}_{60}$-based systems is that up to a certain point the $\mathrm{T}_{c}$ 's increase steadily as either the ET-molecules, or the $\mathrm{C}_{60}{ }^{3-}$ spheres, are increased in separation, i.e., as molecular overlap is reduced and, for example, as the interball $\mathrm{C}_{60}-\mathrm{C}_{60}$ interactions soften. This argues for a BCS mechanism for the electron-pairing interaction in which the electronic density of states at the Fermi surface, which scales with $T_{c}$, increases as molecular overlap is decreased in these organic systems. However, the mechanism of superconductivity in organic superconductors remains an intensely studied mystery at this time!

Finally, one last important note is that the $T_{c}$ 's of the superconducting organic systems are rising at a rapid rate suggesting that they may rival those of the ceramic copper-oxide systems within this decade (see Fig. 11).

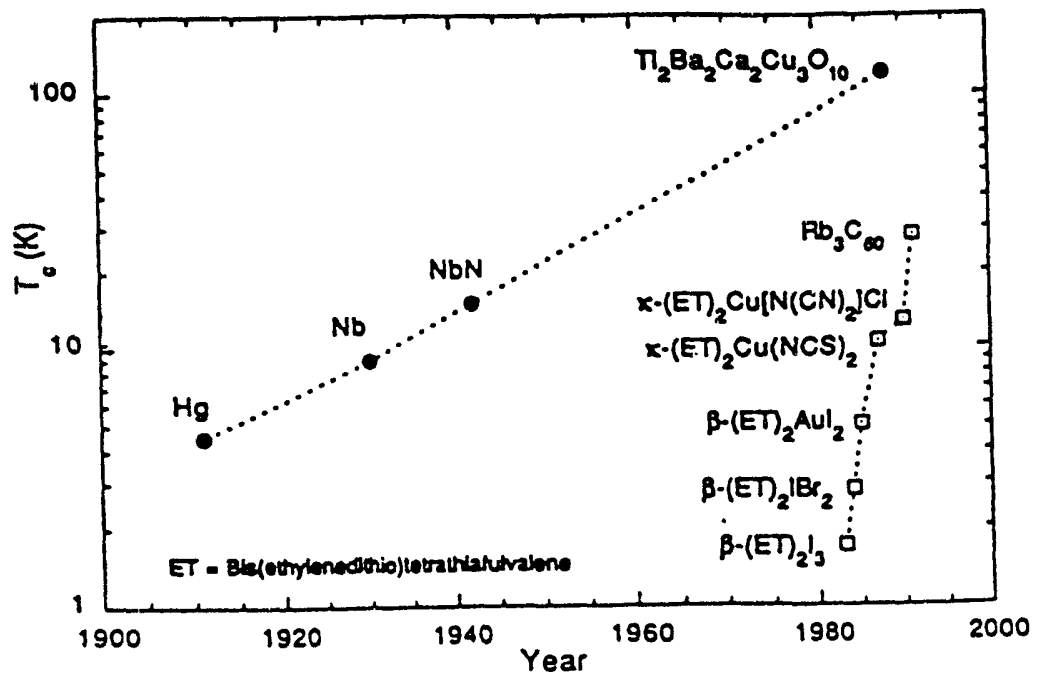

Fig. 11. $\mathrm{T}_{\mathrm{c}}$ vs year. 


\section{Acnowledgments}

Work at Argonne National Laboratory, Sandia National Laboratories, and North Carolina State University is supported by the Office of Basic Energy Sciences, Division of Materials Sciences, U. S. Department of Energy, under contracts W-31-109-ENG-38 and DE04-76DP00789 and grant DE-FG05-86ER45259, respectively.

\section{References}

1. J. M. Williams, A. J. Schultz, U. Geiser, K. D. Carlson, A. M. Kini, H. H. Wang, W.-K. Kwok, M.-H. Whangbo, J. E. Schirber, Science, 252, 1501 (1991).

2. D. Jérome, A. Mazaud, M. Ribault, K. Bechgaard, J. Phys. (Paris) Lett. 41, L95 (1980).

3. (a) N. F. Mott, Proc. Phys. Soc. London Sect. A 62, 416 (1949)

(b) J. Hubbard, Proc. R. Soc. London Ser. A 281, 401 (1964).

4. (a) V. N. Laukhin, E. E. Kostyuchenko, Y. V. Sushko, I. F. Shchegolev, E. B. Yagubskii, JETP Lett. 41, 68 (1985).

(b) K. Murata, M. Tokumoto, H. Anzai, H. Bando, G. Saito, K. Kajimura, T. Ishiguro, J. Phys. Soc. Jpn. 54, 1236 (1985).

5. (a) A. J. Schultz, M. A. Beno, H. H. Wang, J. M. Williams, Phys. Rev. B 33, 7823 (1986).

(b) A. J. Schultz, H. H. Wang, J. M. Williams, A. Filhol, J. Am. Chem. Soc. 108, 7853 (1986).

6. (a) J. E. Schirber, L. J. Azevedo, J. F. Kwak, E. L. Venturini, P. C. W. Leung, M. A. Beno, H. H. Wang, J. M. Williams, Phys. Rev. B 33, 1987 (1986).

(b) J. E. Schirber, L. J. Azevedo, J. E. Kwak, E. L. Venturini, M. A. Beno, H. H. Wang, J. M. Williams, Solid State Commun. 59, 525 (1986).

7. H. Urayama, H. Yamochi, G. Saito, K. Nozawa, T. Sugano, M. Kinoshita, S. Sato, K. Oshima, A. Kawamoto, J. Tanaka, Chem. Lett. 55 (1988).

8. A. M. Kini, U. Geiser, H. H. Wang, K. D. Carlson, J. M. Williams, W. K. Kwok, K. G. Vandervoort, J. E. Thompson, D. L. Stupka, D. Jung, M.-H. Whangbo, Inorg. Chem. 29, 2555 (1990).

9. J. M. Williams, A. M. Kini, H. H. Wang, K. D. Carlson, U. Geiser, L. K. Montgomery, G. J. Pyrka, D. M. Watkins, J. M. Kommers, S. J. Boryschuk, A. V. Strieby Crouch, W. K. Kwok, J. E. Schirber, D. L. Overmyer, D. Jung, M.-H. Whangbo, Inorg. Chem. 29, 3272 (1990).

10. U. Welp, S. Fleshler, W. K. Kwok, G. W. Crabtree, K. D. Carlson, H. H. Wang, U. Geiser, J. M. Williams, V. M. Hitsman, Phys. Rev. Lett. 69, 840 (1992).

11. U. Geiser, A. J. Schuitz, H. H. Wang, D. M. Watkins, D. L. Stupka, .J. M. Williams, J. E. Schirber, D. L. Overmyer, D. Jung, J. J. Novoa, M. -H. Whangbo, Physica C 174, 475 (1991).

12. D. W. Murphy, M. J. Rosseinsky, R. M. Fleming, R. Tycko, A. P. Ramirez, R. C. Haddon, T. Siegrist, G. Dabbagh, J. C. Tully, R. E. Walstedt, J. Phys. Chem. Solids 53, 1321 (1992). 

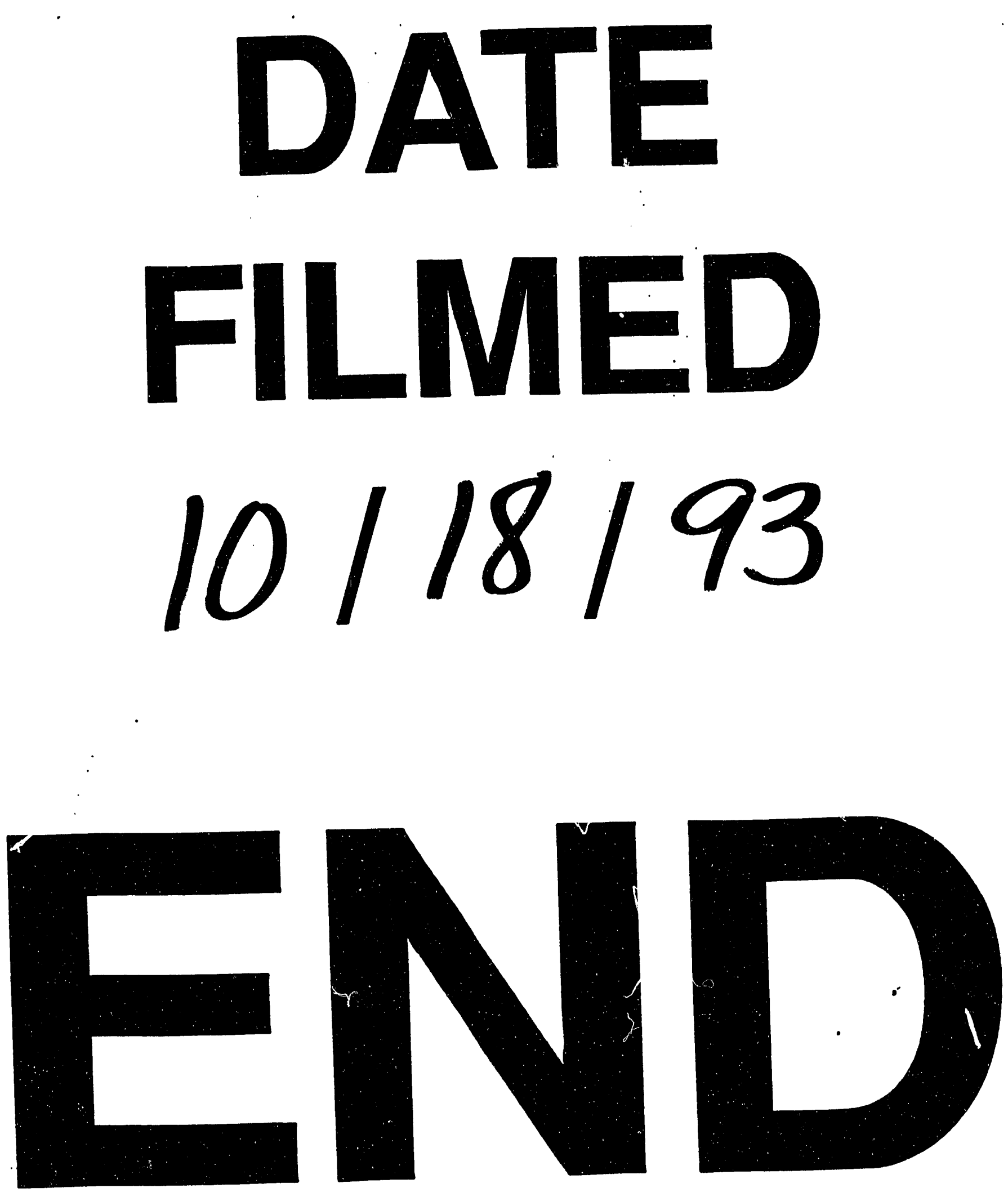
